\title{
KEMANDIRIAN ANAK USIA 5-6 TAHUN DI KOMUNITAS LINGKUNGAN PEMULUNG
}

\author{
Siti Rahma, Ade Dwi Utami, \& Hapidin \\ e-mail: ade.dwi.utami@gmail.com \\ Pendidikan Anak Usia Dini, Universitas Negeri Jakarta \\ Jalan Rawamangun Muka, Jakarta Timur
}

\begin{abstract}
Abstrak: Penelitian ini bertujuan untuk mendapatkan gambaran informasi dan data empiris mengenai kemandirian anak usia 5-6 tahun di komunitas lingkungan pemulung TPST Sumur Batu, Bantar Gebang, Bekasi. Metode penelitian yang digunakan adalah penelitian kualitatif. Penelitian dilakukan pada bulan Mei-Juni 2015 yang pengumpulan datanya dilakukan dengan cara observasi, wawancara, dan dokumentasi. Teknik analisis data yang digunakan yaitu Miles dan Huberman. Pemeriksaan data dilakukan dengan perpanjangan pengamatan, meningkatkan ketekunan, dan triangulasi. Temuan hasil penelitian menunjukkan bahwa kemandirian pada anak usia 5-6 tahun di komunitas lingkungan pemulung dibentuk oleh peran dan sikap orang tua serta peran lingkungan. Kesimpulan penelitian menunjukkan bahwa anak yang mandiri tidak terbentuk dengan sendirinya. Orang tua perlu membekali anak sejak dini untuk bisa melakukan kegiatannya sendiri tanpa harus mengandalkan orang tua.
\end{abstract}

Kata-kata Kunci: kemandirian, anak usia dini, lingkungan pemulung.

\section{INDEPENDANCE OF 4 - 5 YEARS OLD CHILDREN IN THE GARBAGE COLLECTOR COMMUNITY}

\begin{abstract}
The research aims at obtaining information and empirical data of independence of 5 - 6 years old children in the community of garbage collectors TPST Sumur Batu, Bantar Gebang, Bekasi. Using qualitative method, the research was conducted in May and June 2015. The data was collected by observation, interview and document study to analyzed employing Miles and Huberman technique. Data was verified by prolonging observation and triangulation. Research findings showed that self-reliance of 5-6 years old children in the garbage collector community is built by the role and attitude of their parents and the environment. The research conclusion indicates independent children are not built by themselves. The parents should assist the children as early as possible to enable them to do their activities without depend themselves on their parents.
\end{abstract}

Keywords: self-reliance, early age child, garbage collector community.

\section{PENDAHULUAN}

Anak adalah anugerah yang diberikan oleh Allah SWT untuk setiap orang tua. Anak berhak memiliki kesempatan untuk tumbuh dan berkembang dengan baik. Anak juga diyakini sebagai generasi penerus bangsa dalam kehidupannya, sehingga para orang tua wajib menjaga dan mendidik agar anak dapat tumbuh dan berkembang sesuai dengan tahapan perkembangannya.

Pada usia dini, anak akan melalui tahapan perkembangan yang berbeda di setiap tahunnya. Tahapan perkembangan pada masa anak-anak tidak bisa disamakan dengan orang dewasa. Hal ini dikarenakan, anak adalah individu yang sangat unik dan mempunyai kebutuhan dalam mengembangkan berbagai aspek perkembangan yang tidak bisa disamakan dengan orang dewasa.
Salah satu aspek perkembangan yang berkembang pada diri anak yaitu perkembangan psikososial. Perkembangan psikososial adalah perkembangan dari interaksi individu dan untuk memahami satu sama lain dari pengetahuan mereka dan untuk memahami diri mereka sendiri sebagai anggota masyarakat. Perkembangan Psikososial terdiri dari delapan tahapan. Salah satu tahap perkembangan psikososial yang berkembang pada anak adalah autonomy versus shame and doubt. Pada tahap ini, anak harus diberikan kepercayaan, sehingga anak akan berkembang menjadi lebih mandiri.

Kemandirian pada anak usia dini harus diperkenalkan sedini mungkin. Mengenalkan dan mengajarkan kemandirian akan memberikan dampak 
positif bagi perkembangan diri anak. Dampak positif tersebut akan membantu diri anak ketika anak sudah beranjak dewasa. Anak tidak akan selalu bergantung dengan orang tua ketika dalam kehidupan sehariharinya. Selain itu, kemandirian pada anak berbeda dengan kemandirian orang dewasa dan remaja.

Salah satu faktor yang berperan dalam menumbuhkan kemandirian pada anak yaitu lingkungan. Lingkungan seorang anak tentu akan berbeda dengan lingkungan pada anak lainnya. Lingkungan yang berbeda tersebut akan memberikan gambaran kemandirian tiap individu anak. Lingkungan serba ada akan memberikan kesempatan kepada anak dengan sebaik mungkin agar anak mampu mandiri. Dalam hal ini, tidak menutup kemungkinan anak akan mampu mandiri dengan lingkungan tersebut. Lingkungan dengan keadaan serba keterbatasan, akan jauh berbeda kemandiriannya. Hal tersebut menjadikan individu anak harus mampu mandiri tanpa bergantung pada orang lain di sekitarnya.

Salah satu lingkungan dengan kondisi keterbatasan adalah lingkungan pemulung. Lingkungan sekitar pemulung menjadikan anakanak di lingkungan tersebut menjadi lebih kuat dan berusaha untuk mandiri. Kehidupan anak di lingkungan pemulung membuat anak melakukan segala sesuatunya dengan sendiri, sehingga secara bertahap kemandirian akan terbentuk pada dirinya. Kemandirian yang telah terbentuk pada diri anak akan memiliki dampak positif bagi lingkungan sekitar. Anak jadi tidak selalu bergantung dengan orang tuanya, mampu melakukan kegiatannya sendiri sesuai kemampuannya, memiliki kesadaran yang terbentuk untuk tidak selalu mengandalkan orang tuanya saja ketika di rumah. Kemandirian pada anak usia dini yang berada di lingkungan pemulung dapat dilihat pada kenyataan sebagai berikut.

Kemandirian terlihat pada anak di lingkungan pemulung. Salah seorang anak mengerjakan pekerjaan rumah tanpa bergantung kepada orang disekitarnya. Anak tersebut terbiasa merapikan tempat tidurnya tanpa disuruh oleh kedua orang tuanya. Hal ini dilakukan anak ketika orang tuanya terutama ibunya sedang tidak ada dirumah, dikarenakan ibunya sedang bekerja dengan mencari diantara gunungan sampah dan bapaknya sedang bekerja sebagai ojek. Pada lingkungan pemulung tersebut ditemukan juga kemandirian pada anak lainnya. Seorang anak bertanggung jawab terhadap apa yang dilakukannya tanpa meminta bantuan dari orang sekitarnya atau meminta orang sekitar untuk melakukannya. Perbuatan yang tidak sengaja dilakukannya, membuat anak memiliki kemauan untuk membersihkannya. Anak tersebut menunjukkan kemampuan bagaimana cara mengatasi rumusan yang tidak sengaja dilakukannya.

Kemandirian secara umum dimaknai sebagai individu yang mampu melakukan segala sesuatu sendiri. Santrock (2008) menyatakan bahwa, "the term autonomy generally connotes self-direction and independence". Artinya, istilah otonomi pada umumnya mempelajari tentang arah diri dan kemandirian. Hal ini dapat dimaksudkan bahwa, otonomi seseorang mengarahkan dirinya ke arah individualitas untuk berusaha mandiri.

Individu anak yang menunjukkan kemandiriannya merupakan suatu proses ke arah yang lebih baik. Dodge dan Colker (2002) menyatakan bahwa, "autonomy, or independence, is acting with will and control". Dapat diartikan, otonomi atau kemandirian adalah berprilaku baik dan terkontrol. Hal ini karena kemandirian bukan perilaku yang bersifat negatif untuk anak. Dalam hal ini, kemandirian yang berkembang pada anak akan membantu anak menjadi pribadi yang tidak bergantung dengan orang lain disekitarnya.

Kemandirian juga berasal dari kata mandiri yang artinya keadaan dapat berdiri sendiri dan tidak bergantung pada orang lain. Familia (2006) menyatakan bahwa kemandirian dapat diartikan sebagai suatu kemampuan untuk memikirkan, merasakan, serta melakukan sesuatu sendiri atau tidak tergantung pada orang lain. Hal ini berarti, bahwa individu yang mandiri selalu memikirkan sesuatu sendiri dan melakukan sesuatu atas kehendak sendiri tanpa bergantung dari apa yang dipikirkan dan dirasakan oleh orang lain.

Dalam mencapai kemandirian tentu membutuhkan suatu proses yang tidak mudah dicapai begitu saja pada anak. Nilsen (2004) mengatakan bahwa, "autonomy, the process of governing oneself and providing for one's own needs, is the goal of childhood". Dapat diartikan bahwa otonomi, proses yang mengatur diri sendiri, dan menyediakan untuk kebutuhan sendiri, hal tersebut adalah tujuan masa kecil. Dalam hal ini, kemandirian bukan suatu yang instan bagi anak, akan tetapi suatu proses pada diri anak ketahap individu yang mandiri dalam memenuhi kebutuhan dirinya. Hal ini membimbing anak untuk 
tidak bergantung dengan orang lain disekitarnya.

Anak yang belajar mandiri menjadikan dirinya merasa yakin akan sesuatu yang dikerjakannya. Familia (2006:31) menjelaskan bahwa, dengan kebiasaan mandiri yang diajarkan sejak dini, anak akan terbantu untuk memiliki rasa percaya diri dalam menginginkan dan memutuskan sesuatu bagi dirinya sejak dini. Anak yang mandiri berarti orang tuanya telah membimbing anak untuk mampu melakukannya sendiri dan hal tersebut menjadikan anak lebih percaya diri dalam melakukan sesuatu bagi dirinya.

Kemandirian membuat anak berkembang menjadi individuyang tidak selalu mengandalkan orang lain dan berkembang ketahap kedewasaan sesuai usianya. Yamin \& Sanan (2010) menyatakan bahwa, pada faktanya semua usaha untuk membuat anak menjadi mandiri sangatlah penting agar anak dapat mencapai tahapan kedewasaan sesuai dengan usianya. Hal ini dimaksud, bahwa setiap orang tua akan berusaha membuat anaknya menjadi pribadi yang mandiri, agar dapat mencapai kemandirian pada diri anak.

Konsep kemandirian terbentuk diberbagai bidang aspek perkembangan, Mena dan Eyer (2001) mengemukakan bahwa, "the necessary capabilities lie in three separate domains - the physical (control), the cognitive (understanding), and the emotional (willingness)". Dapat diartikan, kemampuan yang diperlukanterletak padatiga domain yang terpisah fisik (kontrol), kognitif (pemahaman), dan emosional (kemauan). Ketiga domain tersebut pasti akan berproses pada individu anak yang mandiri. Aktivitas yang dilakukan tentu berdasarkan atas kendali atau kontrol dari dirinya, pemahaman anak terhadap masalah yang dihadapinya, dan kemauan dari diri sendiri dalam melakukan sesuatu.

Kemandirian juga terbentuk pada aspek perkembangan emosi dengan ditunjukkan ketika anak melepaskan ketergantungannya pada orang tua.lebih lanjut Santrock (2008) menyatakan bahwa, "one aspect of autonomy that is especially important is emotional autonomy, the capacity to relinquish childlike dependencies on parents". Salah satu aspek otonomi yang sangat penting adalah emosional otonomi, dimana kapasitas pada anak kecil untuk melepaskan dependensi pada orang tua. Hal ini berarti, anak yang berusaha ingin mandiri, berusaha melepaskan ketergantungannya pada orang tua untuk menjadi lebih mandiri, sehingga hal ini akan memacu emosi anak terhadap keinginannya tersebut.
Setiap individu yang mandiri tentu akan terlihat dari dirinya. Hal tersebut akan menunjukkan ciri-ciri kemandirian seseorang. Green (2013) mengemukakan bahwa, "a child's growing independence is demonstrated through the manipulation of physical objects and spaces, providing a child with a sense of individuality". Kemandirian seorang anak tumbuh ditunjukkan melalui manipulasi benda-benda fisik dan ruang, memberikan anak dengan rasa individualitas. Artinya, individu anak yang mandiri memerlukan ruang khusus untuk dirinya. Hal ini dikarenakan anak yang sudah mulai mandiri, membutuhkan privasi untuk dirinya. Individualitas tersebut selalu dimiliki oleh orang-orang yang memiliki kemandirian pada dirinya.

Individu yang mandiri termasuk ke dalam ciri individu yang dapat mengaktualisasikan dirinya. Feist, dkk., (2013) mengemukakan bahwa, "self-actualizing people are autonomous and depend on themselves for growth even though at some time in their past they had to have received love and security from others". Orang-orang yang mengaktualisasi diri merupakan orang-orang yang mandiri dan bergantung pada diri mereka sendiri untuk bertumbuh walaupun di masa lalunya mereka pernah menerima cinta dan rasa aman dari orang lain. Hal ini menunjukkan bahwa individu yang mandiri mampu mengaktualisasikan dirinya dengan tidak bergantung dengan orang lain disekitarnya

Individu yang mandiri akan memiliki kekuatan untuk melakukan kegiatannya sendiri tanpa bergantung dengan orang lain. Mena dan Eyer (2001:81) mengemukakan bahwa, "they discover the power they possess, and they push toward independence".Mereka menemukan kekuatan yang dimiliki, dan mereka mendorong menuju kemandirian. Hal ini dapat dimaksudkan bahwa, individu anak yang memiliki kekuatan dan keberanian, akan mengarahkan anak pada proses kemandirian.

Kemandirian yang terbentuk pada anak dipengaruhi oleh berbagai faktor yang berbeda-beda. Asrori dalam Yamin dan Sanan (2010) menyatakan bahwa, faktor-faktor yang mempengaruhi kemandirian adalah: (1) keturunan, (2) pola asuh orang tua, (3) sistem pendidikan di sekolah, dan (4) sistem kehidupan di masyarakat.

Individu anak yang mandiri juga dapat dibentuk dari sebuah lingkungan. Erikson dalam Trawick-Smith (2003) menyatakan bahwa, "Erikson has proposed that creating environments in which children can become independent in thought and 
action will contribute to a sense of autonomy". Dapat diartikan, Erikson telah mengusulkan bahwa menciptakan lingkungan di mana anak-anak dapat menjadi mandiri dalam berpikir dan bertindak akan memberikan kontribusi untuk rasa otonomi. Hal ini dapat dimaksudkan bahwa, lingkungan turut memberikan pengaruh terhadap kemandirian anak, karena dengan lingkungan tempat tinggal anak tentu akan membentuk proses berpikir sehingga menjadikan anak mandiri.

Kemandirian seorang anak juga tidak hanya dipengaruhi oleh orang tua dan lingkungan. Nilsen (2004) menambahkan bahwa "caregivers still need to be protective and restrictive while allowing the child opportunities to begin to be more independent". Dapat diartikan, pengasuh perlu melindungi dan untuk sementara memungkinkan memberikan kesempatan kepada anak untuk mulai independen. Hal ini dapat dimaksudkan bahwa, pengasuh juga memberikan pengaruh kepada anak dalam proses kemandirian. Apabila anak diasuh oleh pengasuh dan pengasuh memberikan kesempatan kepada anak untuk mandiri, maka kemungkinan anak akan mulai berusaha sendiri sesuai kemampuan yang dimilikinya.

Kemandirian secara umum dapat dilakukan oleh anak yang sudah mulai memasuki tahap autonomy. Papalia, Olds, dan Feldman (2009:233) menyatakan bahwa autonomy versus shame and doubt Erikson's second stage in psychosocial development, in which children achieve a balance between self-determination and control by others. Kemandirian vs rasa malu dan ragu-ragu, tahap kedua dalam perkembangan psikososial Erikson, dimana anak-anak baru mencapai keseimbangan dirinya untuk menentukan nasib sendiri dan kontrol dari orang lain. Hal ini berarti, kepercayaan yang telah diterimanya telah berkembang ke arah kemandirian, di mana anak dapat menentukan keputusannya sendiri dengan tetap terkontrol dari orang disekitarnya.

Dalam perkembangan personal-sosial, anak usia 6 tahun juga menunjukkan kemandiriannya.
Piaget dalam Allen dan Marotz (2010) menyatakan bahwa, anak sudah menjadi lebih tidak bergantung pada orang tuanya karena lingkaran pertemanannya semakin luas, masih membutuhkan kedekatan dan pengasuhan, namun mempunyai dorongan untuk melepaskan diri dan "tumbuh menjadi dewasa". Artinya, pada usia ini anak sudah mampu mandiri dengan tidak bergantung pada orang tuanya, walaupun anak masih membutuhkan kasih sayang dari orang tuanya, bukan berarti anak pada usia ini belum mandiri.

Kemandirian anak juga berkembang pada aspek perkembangan kognitif. Hal ini dapat diketahui dari karakteristik kemandirian pada anak usia prasekolah yang dinyatakan oleh McDevitt dan Ormrod. Lebih lanjut McDevitt dan Ormrod menyatakan bahwa "with their growing independence, preschoolers begin to get their own ideas about the activities they want to pursue; for example, they may undertake simple art projects, make houses and roadways in the sandbox, or play "house" with other children".

Dapat diartikan, mereka tumbuh dengan kemandirian, anak-anak prasekolah mulai mendapatkan ide mereka sendiri mengenai kegiatan yang mereka ingin kerjakan; misalnya, mereka dapat melakukan proyek seni sederhana, membangun rumah dan jalan raya di kotak pasir, atau bermain "rumah" dengan anak lainnya. Berarti, pada usia ini anak sudah mulai menggunakan pikirannya untuk kegiatan yang disukainya

Berdasarkan uraian tersebut, maka dapat dikatakan bahwa kemandian pada anak perlu dikembangkan sejak dini. Dengan demikian, rumusan penelitian ini adalah bagaimana kemandirian anak usia 5-6 tahun di komunitas lingkungan pemulung TPST Sumur Batu, Bantar Gebang, Bekasi. Penelitian ini bertujuan untuk mendapatkan gambaran informasi dan data empiris mengenai kemandirian anak usia 5-6 tahun di komunitas lingkungan pemulung TPST Sumur Batu, Bantar Gebang, Bekasi.

\section{METODE PENELITIAN}

Metode yang digunakan adalah penelitian kualitatif. Penelitian kualitatif adalah suatu penelitian yang ditujukan untuk mendeskripsikan aktivitas sosial dengan melihat, memahami, mendalami suatu fenomena dalam konteks sosial yang sesuai dengan kenyataan yang ada di lapangan. Dalam mengkaji fenomena yang tampak menggunakan penelitian kualitatif fenomenologi. Hal ini dimana fenomenologi merupakan penelitian untuk menggali, mengkaji, mendalami, serta mendeskripsikan suatu fenomena yang terjadi dengan melakukan interaksi dengan subjek ataupun sumber informan yang akan diteliti.

Penelitian ini dilaksanakan di Tempat Pengolahan Sampah Terpadu (TPST) Sumur 
Batu, Bantar Gebang, Bekasi yang beralamat di Jl. Pangkalan 2, Bantar Gebang, Bekasi. Waktu penelitian dilaksanakan pada tahun ajaran 20152016, yaitu pada bulan Mei-Juni 2015. Pada bulan tersebut, kegiatan anak masih berjalan efektif saat di sekolah dan masih memungkinkan peneliti untuk meneliti dan memperoleh data ketika selesai pulang sekolah.

Subjek dalam penelitian ini adalah anak usia 5-6 tahun di lokasi TPST Sumur Batu, Bantar Gebang, Bekasi. Adapun data yang dikumpulkan meliputi: (a) tanggung jawab, (b) inisiatif, (c) kemampuan bersosialisasi, dan (d) pengendalian emosi. Keempat data tersebut bersumber dari anak dan orangtua. Pengumpulan data dilakukan dengan melakukan observasi, wawancara, dan studi dokumentasi.

Peneliti memilih teknik observasi partisipan, karena peneliti ingin menjalin hubungan yang lebih baik antara peneliti dengan subjek ataupun informan secara mendalam guna untuk mengetahui kemandirian pada anak. Peneliti berpartisipasi langsung dalam kegiatan sehari-hari yang akan dilakukan anak. Hal yang diamati oleh peneliti antara lain aktivitas sehari-hari di rumah yang menunjukkan kemandiriannya di komunitas lingkungan pemulung TPST Sumur Batu, Bantar Gebang, Bekasi.

Untuk wawancara, peneliti menggunakan wawancara tidak terstruktur agar anak dan informan tidak akan terkesan seperti diwawancarai, namun pengambilan data tetap akan disesuaikan dengan pedoman catatan wawancara yang telah dibuat. Topik wawancara yang akan diajukan dalam penelitian antara lain: rutinitas sehari-hari yang dilakukan anak, cara dan tujuan mendidik anak, harapan terhadap diri anak, bentuk dukungan yang diberikan kepada anak, memberlakukan peraturan atau tidak ketika di rumah, peran orang tua ketika anak berbuat kesalahan. Peneliti juga menggunakan teknik dokumentasi dalam melakukan penelitian guna untuk mendapatkan data yang otentik dan akurat. Peneliti mendokumentasikan aktivitas keseharian anak ketika di rumah.

Analisis data dalam penelitian kualitatif ini menggunakan teknik analisis Miles dan Huberman seperti yang tersaji pada gambar 1 .

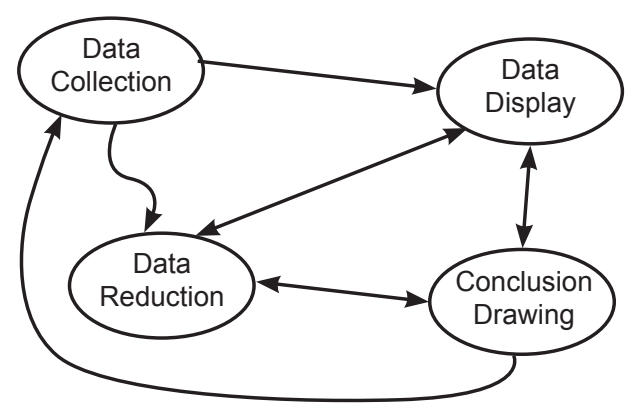

Gambar 1. Model analisis Interaktif Miles dan Huberma

Berdasarkan gambar 1, teknik analisis Miles dan Huberman meliputi (a) reduksi data, (b) display data, dan verifikasi data. Hubungan antar tiap komponen analisis data Miles dan Huberman, yaitu proses analisis data kualitatif dilakukan secara bersamaan dan terusmenerus sehingga datanya jenuh. Kejenuhan data ditandai dengan tidak diperolehnya lagi informasi baru yang diperoleh dari hasil catatan lapangan, catatan wawancara, dan catatan dokumentasi selama penelitian. Sedangkan untuk teknik keabsahan yang digunakan yaitu perpanjangan pengamatan, meningkatkan ketengunan, dan triangulasi. Hal ini untuk meningkatkan derajat kepercayaan terhadap data penelitian, guna untuk mengetahui data yang sudah didapat benar atau salah dan untuk lebih cermat lagi saat melakukan analisis data.

\section{HASIL DAN PEMBAHASAN}

Hasil analisis data kualitatif menunjukkan bahwa kecenderungan pola kemandirian yang tampak pada anak adalah mandiri dalam melakukan aktivitas kesehariannya di rumah. Kemandirian anak yang ditunjukkan terlihat ketika anak menunjukkan keinginan dan kemauannya untuk menyelesaikan masalahnya sendiri tanpa harus disuruh terlebih dahulu, sehingga anak menunjukkan inisiatif terhadap situasi yang mendorong dirinya untuk melakukannya. Inisiatif yang ditunjukkan juga terlihat ketika anak memiliki keinginan dan kemauan untuk membantu orang tuanya ketika di rumah. Anak membantu orang tua bukan atas perintah, tetapi anak mau dan ingin membantu orang tuanya sendiri. Inisiatif yang terbentuk pada anak berdasarkan ajaran dan didikan dari orang tua untuk bisa melakukan apa-apa sendiri. Cara orang tua tersebut sebagai proses bagi diri anak untuk terbiasa melakukan kegiatannya sendiri. Orang tua selalu mengajarkan terlebih dahulu kepada anak guna untuk menumbuhkan kesadaran pada diri anak untuk tidak selalu bergantung dengan orang tuanya. Orang tua juga tidak memanjakan anak-anaknya ketika di rumah. Berikut analisis data berdasarkan catatan wawancara dengan orang tua anak. 
Didikan (CWOAM.1, JW.13, K.1). Kalau saya mendidik anak-anak saya harus bisa melakukan apa-apa sendiri, kaya mandi ge, makan (CWOAM.1 , JW.13 , K.2). Tapi si diperintahkan dulu sama orang tuanya, terus anak-anak melakukannya (CWOAM.1 , JW.13 , K.3). Besok-besokkannya mereka udah biasalah buat ini itu melakukan kegiatan yang bermanfaat (CWOAM.1, JW.13, K.4). Ya kita mah ngajarinnya juga biar bocah tuh biar ada pikirannya gitu, jangan segala ngandelin orang tua, ngambil nasi nyuruh orang tua, ambil lap nyuruh orang tua, ya jangan kaya gitu pingin kita mah (CWOCP.1, JW.26 , K.4). Pertama-tama saya ajarin begitu si, terus mungkin udah kebiasaan tau kalau misalnya yak abis makan diberesin, ya pokoknya saya ga manjain anakanak saya (CWOAM.1 , JW.13, K.6). Jadi inisiatifnya sendiri, jadi pernah diolah (CWOAM.1, JW.13, K.7). Kita tuh ngedidik anak gimana supaya anaknya ada kerajinan, keterampilan (CWOAM.1, JW.13, K.12). Kalau misal dirumah ga bereslah, kaya tempat tidur pada kotor ya disapuin, ya bagaimana jalan baiknya lah (CWOAM.1, JW.14, K.4). Kesimpulannya si ya, sebenernya apa-apa mereka tuh bukan dari anak sendiri, tapi dari arahan, didikan, saran, ajaran orang tua (CWOAM.1 , JW.14, K.7). Intinya si "anak-anak saya harus bisa sendiri” (CWOAM.1, JW.14, K.12).

Tanggung jawab merupakan salah satu bentuk kemandirian yang ditunjukkan ketika anak diperintahkan atau diamanahkan oleh orang tua untuk membantunya dan anak mau melaksanakan perintah tersebut. Tanggung jawab juga ditunjukkan ketika anak mau bertanggung jawab pada dirinya sendiri. Hal ini ditunjukkan ketika anak mau merapikan pakaian sekolah yang telah selesai dikenakannya. Tanggung jawab yang terbentuk pada anak karena anak diajarkan untuk bisa bertanggung jawab pada dirinya sendiri. Orang tua juga selalu membiasakan untuk memberitahukan apabila ada pekerjaan rumah yang diberikan ibu guru saat di sekolah, segera dikerjakan. Anak juga diajarkan untuk selalu bertanggung jawab pada dirinya sendiri ketika bermain atau kegiatan lainnya. Orang tua juga menyatakan bahwa, dengan menyuruh anaknya melaksanakan perintah orang tuanya guna untuk menjadikan anak mandiri.Hal ini karena orang tua memandang jarak untuk dimintai tolong tidak terlalu jauh.

Kita mendidik anak-anak ketika pulang sekolah, bajunya jangan asal geletak aja dimana mana, tetapi harus dibereskan (CWOAM.1, JW.14, K.2). Kalau ada pekerjaan rumah dari sekolahnya, ya dikerjain pr nya (CWOAM.1, JW.14, K.3). Tapi kan cuma hanya sekedar dari sini kesitu, tolong ambilin kalau adenya pipis, ya dia mau si, mau ambilin, gitu doang (CWOCP.1 , JW.12 , K.4). Ya kan ibaratnya supaya anak kita mandiri lah, terus fokus sama pelajaran (CWOCP.1, JW.12, K.5).

Kemandirian yang ditunjukkan anak yaitu kemampuan bersosialisasi, dimana anak berinteraksi dengan teman-temannya. Anak mudah menyesuaikan diri, beradaptasi dengan teman-teman, sehingga anak tidak pernah malu untuk berinteraksi dengan mengajak teman-temannya bermain bersama. Kemampuan bersosialisasi juga terlihat ketika anak berinteraksi dengan peneliti yang baru dikenalinya. Anak mudah menyesuaikan diri, beradaptasi dengan orang baru yang ditemuinya. Anak tidak malu dan selalu mengajak peneliti untuk bermain bersamanya. Kemandirian yang terbentuk pada anak karena anak diajarkan untuk tidak malu dengan orang lain. Anak juga diajarkan untuk selalu menghargai orang lain serta tidak usah takut ketika bertemu dengan orang yang baru dikenalinya. Orang tua juga mengajarkan kepada anak untuk berani beradaptasi dengan orang lain. Anak diberi kebebasan untuk bermain, tetapi harus dalam tempat dan waktunya. Dapat dimaksudkan bahwa ketika anak bermain, jangan jauh-jauh, sebab agar mudah dipantau oleh orang tua. Hal ini dapat ditunjukkan dari hasil catatan wawancara dengan orang tua anak sebagai berikut.

Kalau saya memang ga ngajarin mereka buat malu (CWOAM.1 , JW.15, K.1). Kalau ada orang ya ditanya "ada perlu apa", "tujuannya apa dan sama siapa", kan gitu harus ditanya (CWOAM.1, JW.15, K.2). Saya juga mengajarkan, kalau ada tamu, hargai (CWOAM.1 , JW.15, K.3). Kalau kita ga hargai, nanti kita dianggapnya sombong (CWOAM.1, JW.15, K.4). Saya juga berpesan, kalau ada orang lain, hadapin dan jangan takut (CWOAM.1, JW.15, K.7). Jangan malu-malu lah sama temen, kan kalau malu-malu, buat bergaul sama siapa aja lama kenalnya (CWOCP.1, $J W .28, K .2)$. Kita ajarin mentalnya juga gitu, mental untuk keberanian melakukan apapun sendiri, untuk beradaptasi dengan seseorang (CWOCP.1, JW.12 , K.14). Bilamana ada apa-apa, ya jangan suka mengadu-ngadu gitu lah sama mama atau bapaknya (CWOCP.1 , JW.12 , K.15). Maksudnya, kebebasan anak ya kita beri, cuma ada tempat dan waktunya gitu, yang tepat gitu (CWOCP.1, JW.13, K.6). Dimana tempat untuk bermain, bukannya main dikebon-kebon (CWOCP.1 , JW.13 , K.7). Orang tua harus paham 
lah semestinya anak ini main apa (CWOCP.1, JW.13 , K.8). Semakin kesana semakin berat (CWOCP.1, JW.13 , K.9). Ibaratnya bilamana ada orang tua kita ada urusan apa-apa, supaya dia beradaptasi gitu (CWOCP.1 , JW.13 , K.10).

Kemandirian yang ditunjukkan juga terlihat ketika anak hendak melakukan kegiatannya sendiri dengan pengendalian emosi yang ditunjukkannya. Pengendalian emosi tersebut berkaitan ketika anak memiliki kemauan untuk melakukan sesuatu dan anak melakukan dengan caranya sendiri tanpa bergantung dengan orang tua. Dalam hal ini, dengan menggunakan caranya sendiri, anak harus bisa mengendalikan emosinya. Pengendalian emosi yang ditunjukkan anak dikarenakan anak menyadari bahwa dirinya tidak bergantung dengan orang tua, sehingga anak harus bisa mengendalikan emosinya sendiri agar tidak terjadi sesuatu yang dapat membahayakan dirinya. Orang tua selalu mengingatkan kepada anaknya untuk selalu berhati-hati ketika anak sedang ingin melakukan sesuatu. Hal ini karena orang tua tidak setiap waktu memantau atau mendampingi anak-anaknya. Ajaran dan didikan tersebut selalu menjadi bekal bagi anak untuk tetap berhati-hati.
Kita disini juga kasih didikan, kalau mau apa-apa, harus hati-hati, soalnya kan kita ga selalu ngawasin mereka (CWOAM.1, JW.16, K.3). Kalau anak ga diajarin, anak mana mungkin bisa sih tanpa orang tua (CWOAM.1, JW.16 , K.4).Kan kita ngajarin Cindy biar apa-apa sendiri, jangan selalu ngandelin orang tua (CWOCP.1, JW.29, K.3). Kita ge juga bilang harus hati-hati kalau lagi ngapa-ngapain (CWOCP.1, JW.29, K.4). Soalnya kan kita ga setiap waktu mantau Cindy kalau lagi main atau apa ge dan sendiri (CWOCP.1 , JW.29 , K.5). Tetanggatetangganya juga ga pernah ngelarang Cindy buat ini itu (CWOCP.1 , JW.21, K.5). Maksudnya hem gini, kalo Cindy lagi mau metik cerry, tetangga yang liat ga pernah ngelarang buat naik, karena yang penting Cindy nya mah hati-hati aja ge (CWOCP.1 , JW.21 , K.6). Disini mah juga tetangganya ga ngatur atau ngelarang juga (CWOCP.1, JW.30 , K.2). Tapi yang penting Cindy nya hati-hati (CWOCP.1, JW.30, K.3).

Gambar 2 berikut merupakan bagan temuan penelitian yang didapat berdasarkan hasil pengamatan di komunitas lingkungan pemulung TPST Sumur Batu, Bantar Gebang, Bekasi.

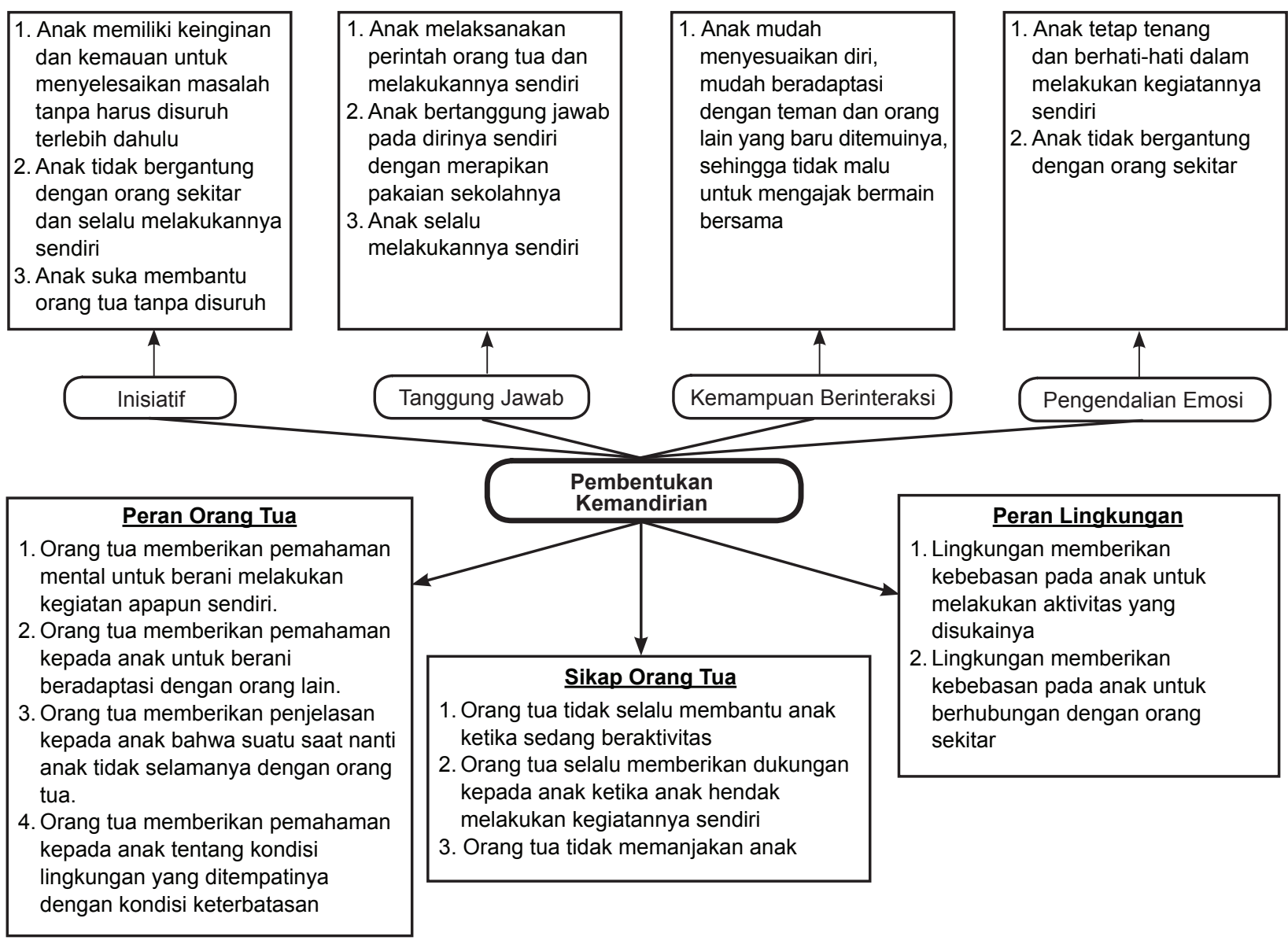

Gambar 2. Bagan temuan penelitian 
Berdasarkan penjabaran pada gambar 2, dapat dideskripsikan bahwa kemandirian anak di komunitas lingkungan pemulung yaitu menunjukkan inisiatifnya ketika memiliki keinginan dan kemauan dalam menyelesaikan masalah dan membantu orang tuanya, mau bertanggung jawab melaksanakan perintah orang tua dan bertanggung jawab pada diri sendiri, bersosialisasi dengan siapa saja dengan mengajak bermain bersama, serta mampu mengendalikan emosi ketika melakukan sesuatu sendiri dengan caranya sendiri. Hal yang utama dari semuanya yaitu anak selalu melakukannya sendiri tanpa bergantung dengan siapapun.

Anak dari keluarga yang tinggal di lingkungan pemulung TPST Sumur Batu, Bantar Gebang, Bekasi khususnya keluarga dari subjek penelitian mendidik anak untuk menjadikan anak-anaknya mandiri. Cara mendidik orang tua di rumah akan membentuk pribadi pada anak untuk tidak bergantung dengan siapapun. Dalam hal ini, orang tua berharap kelak nanti anak bisa mandiri tanpa orang tua di sampingnya.Maka dari itu, setiap harinya orang tua tidak pernah melayani anak ataupun membantu anak selagi anak itu bisa melakukannya sendiri.Orang tua selalu mengingatkan kepada anak untuk berhati-hati ketika melakukan sesuatu sendiri, baik ketika anak di rumah ataupun di luar rumah yang dapat membahayakan ataupun tidak.

Keluarga dari subjek penelitian juga tidak melarang anak untuk bermain dengan siapa saja. Anak selalu diajarkan hidup prihatin dengan kondisi yang ada.Anak tidak banyak menuntut dan meminta kepada orang tuanya.Keinginan orang tua tetap nomer satu yaitu anak-anaknya sekolah dengan benar dan sungguh-sungguh serta menjadi anak yang mandiri.

\section{PENUTUP}

\section{Kesimpulan}

Kemandirian anak usia 5-6 tahun di TPST

Sumur Batu, Bantar Gebang, Bekasi menunjukkan kemandiriannya dalam pola yang berbeda-beda setiap harinya. Anak menunjukkan kemandiriannya ketika di rumah.Mereka tidak pernah meminta orang tua atau orang disekitar untuk membantunya.

Anak menunjukkan inisatifnya ketika berkaitan dengan keinginan dan kemauan untuk menyelesaikan masalahnya tanpa harus disuruh terlebih dahulu dan tidak bergantung dengan orang tua.Inisiatif juga ditunjukkan ketika anak ingin membantu orang tuanya ketika di rumah dan hal tersebut berdasarkan atas kemauan dan keinginan anak membantu orang tuanya. Keragaman lain dari kemandirian yang ditemukan yaitu tanggung jawab. Tanggung jawab yang ditunjukkan berkaitan dengan perintah yang diberikan orang tua dan anak melaksanakan perintah tersebut.Tanggung jawab juga ditunjukkan ketika anak mau bertanggung jawab pada dirinya sendiri dengan mau merapikan pakaian sekolahnya tanpa harus bergantung dengan orang tua untuk membereskannya.

Keragaman lain dari kemandirian adalah kemampuan bersosialisasi. Anak menunjukkan dirinya mudah beradaptasi, mudah menyesuaikan diri dengan teman-teman dan orang lain yang baru ditemuinya. Hal ini menjadikan anak tidak malu untuk selalu mengajak teman-teman dan peneliti untuk bermain bersama dengan dirinya. Keragaman lain dari kemandirian adalah pengendalian emosi. Pengendalian emosi berkaitan dan ditunjukkan ketika anak ingin melakukan sesuatu dan anak melakukan dengan caranya sendiri tanpa harus bergantung dengan orang tuanya.Ketika melakukan dengan caranya sendiri, anak tetap berhati-hati melakukannya. Hal ini karena anak tidak setiap waktu dipantau oleh orang tua.

Pola-pola yang ditunjukkan pada anak merupakan kemandirian yang dimiliki anak di komunitas lingkungan pemulung.Kemandirian tersebut tentu tidak terbentuk dengan sendiri pada diri anak.Dalam hal ini, peran dan sikap orang tua turut memberikan pengaruh terhadap perkembangan kemandirian anak sejak dini.Orang tua selalu memberikan pemahaman kepada anak untuk berani melakukan kegiatan apapun sendiri. Orang tua juga memberikan penjelasan kepada anak bahwa suatu saat nanti anak tidak selamanya akan hidup dengan orang tua, sehingga orang tua sejak dini membiasakan anak untuk melakukan kegiatannya sendiri. Pembentukkan kemandirian itu juga bukan hanya dari peran orang tua saja, tetapi sikap orang tua kepada anak juga turut memberikan pengaruh. Sikap orang tua tidak memanjakan anaknya dan selalu mendukung anak-anaknya untuk lebih mandiri. Pembentukan kemandirian pada anak juga dapat dibentuk dari lingkungan.Lingkungan memberikan 
kebebasan pada anak untuk melakukan aktivitas yang disukainya tanpa dibatasi dan lingkungan memberikan kebebasan pada anak untuk berhubungan dengan orang sekitar.

\section{DAFTAR PUSTAKA}

Allen, K. Eileen \& Lynn. (2010). Profil perkembangan anak. Jakarta: Indeks.

Dodge, Diane Trister \& Laura J. Colker. (2002). The creative curriculum for early childhood (third edition). Amerika: Teaching Strategies.

Familia, Tim Pustaka. (2006). Membuat prioritas melatih anak mandiri. Yogyakarta: Kanisius.

Feist, J., dkk. (2013). Theories of personality (eighth edition). New York: McGraw Hill.

Feldman, R. S. (2000). Understanding psychology (fourth edition). New York: McGraw Hill.

Green, C. "A sense of autonomy in young children's special places", International Journal for Early Childhood Encironment Education, 1 (1), 8-31.2013. http://www.naaee.net/sites/default/ files/publications/IJECEE/6.\%20IJECEE\%20 First $\% 20$ Issue $\% 20$ Research $\% 20$ Study $\% 20$ Sense\%20of\%20Autonomy\%20FINAL.pdf. (Diunduh 27 Februari 2015 - 14:20).
McDevitt, T. M., \& Ormrod, J.E. (2002). Child development and education. New York: Pearson Education.

Mena, J. G., \& Eyer, D.W. (2001). Infants, toddlers, and caregivers (fifth edition). New York: Mayfield Publishing Company.

Nilsen, B. A. (2004). Week by week: documenting the development of young children, third edition. New York: Thomson.

Papalia, D.E., dkk. (2009). A child's world: infancy through adolescence, eleventh edition. New York: McGraw-Hill.

Santrock, J. W. 2008. Adolescence (twelfth edition). New York: McGraw-Hill.

Smith, J. T. (2003). Early childhood development: a multicultural perspective, third edition. New York: Pearson Education.

Yamin, M., \& Sanan, J. S. (2010). Panduan pendidikan anak usia dini (PAUD). Jakarta: Gaung Persada. 